\title{
The Effect of Learning Strategy and Education Background on Student Learning Outcomes of Islamic Junior High Public School (MTsN 1) Simalungun
}

\author{
Erni Hanim Siregar ${ }^{1}$, Rahmat Hidayat ${ }^{2}$ \\ ${ }^{1}$ Teacher in Islamic Junior High Public School (MTsN 1) Simalungun, Indonesia \\ ${ }^{2}$ Lecturer of Magister Program in Tarbiyah and Teacher Training Faculty of State Islamic University of North \\ Sumatera, Indonesia \\ rusdiananda.1972@gmail.com
}

\begin{abstract}
This research deals with The Effect of Learning Strategy and Education Background on Student Learning Outcomes of Islamic Junior High Public School (MTsN 1) Simalungun. One effort that can be done to improve learning outcomes is to improve the quality of learning by implementing better learning strategies.The method used in this study is a quasiexperimental method. The results show that there is an interaction between learning strategies with educational backgrounds, where students with an educational background in islamic elementary school (MI) are better taught using generative learning strategies compared to using expository learning strategies, while students with educational background in elementary school (SD) is better taught by using expository learning strategies compared to generative learning strategies. This is evidenced by the price of $F_{\text {count }} 35.48>F_{\text {table }} 3.984$.
\end{abstract} Keywords: Learning Strategy, Learning Outcomes, Education Background, Students.

\section{Introduction}

One effort that can be done to improve learning outcomes is to improve the quality of learning by implementing better learning strategies. Learning activity is the core of educational activities themselves that are inseparable from the role of the teacher. The ability of teachers to master learning technology to plan, design, implement and evaluate and make feedback is an important factor in achieving learning goals. The ability of teachers to master learning materials, teaching styles, use of media, determination of strategies and selection of learning methods are the efforts to smooth the learning process and improve learning outcomes.

The application of the right learning strategy is an option if you want learning to be effective and efficient, as revealed by Slameto (2005: 65) so that students can learn well then the learning strategy is carried out effectively and efficiently. It is said to be effective if the learning strategy produces as expected or in other words the goal is achieved. It is said to be efficient if the learning strategy applied is relatively using minimum energy, effort, cost and time.

There are various kinds of learning strategies that can be used by teachers in the classroom, one of which is a generative learning strategy. But it needs to be realized that the strategy is not the best or the worst, because the strategy has advantages and disadvantages. In this case Sudjana (2002: 76) states that "each method has advantages and benefits". In generative learning, the teacher is more of a facilitator like a team that works with students in exploring information sources and the teacher is in charge of helping students to achieve learning goals.

Teachers in generative learning are more concerned about encouraging students to be actively involved in constructing their own knowledge desired by students. Generative learning strategies aim to foster students in developing students' cognitive, affective and psychomotor aspects in a comprehensive manner and interact with their environment. Generative learning 
strategies emphasize learning where students discover for themselves what they are learning, not knowing from others in this case the teacher as happens in expository learning.

While the expository learning strategy is teacher-centered learning, students are less empowered and communication that occurs is generally one-way. In the process of expository learning strategies students can only solve the problem in the manner shown by the teacher, so that students are waiting for an explanation from the teacher or teacher to teach the material focused on learning outcomes only, and students are less daring to ask or respond to problems in learning Fiqh Jurisprudence.

\section{Review of Literatures}

\subsection{Learning Outcomes}

The discussion of learning outcomes cannot be separated from the study of the concept of learning itself, because learning outcomes are obtained after going through the learning process carried out by students. Siregar and Nara (2011:4) cite Burton's opinion explaining that learning is a process of changing behavior in individuals because of the interaction between individuals and individuals and their environment so that they are better able to interact with their environment.

Aunurrahman (2011: 36) explains learning is the interaction of individuals with their environment in the form of humans or other objects that allow individuals to gain experiences or knowledge, both experience or new knowledge or something that has been obtained or discovered before but raises attention again for individuals thus allowing interaction.

Sopiatin and Sahrani (2011: 66) explain learning is a process of behavior change, both in terms of knowledge, skills, and attitudes, from not knowing to knowing, and not understanding to understanding, from doubt to being convinced, with words of success learning characterized by changes in behavior occur in self-learning individuals. Singer as quoted by Siregar and Nara (2011: 4) explains that learning is a change in behavior that is relatively fixed due to practices or experiences that arrive in certain situations.

Darmayanti (2009: 5) explains learning is a process that results in changes in behavior. After learning, individuals experience changes in their behavior including cognitive, affective and psychomotor aspects. Mardianto $(2009 ; 35)$ explains learning is a business or activity that aims to make changes in a person including changes in behavior, attitudes, habits, science, skills and so on.

Komalasari (2010: 2) defines learning as a process of changing behavior in the knowledge, attitudes, and skills acquired in a long period of time and provided that changes do not occur due to maturity or temporary changes for some reason. Shaffat (2009: 2) explains learning is a process to get knowledge that is known to the public or moral values that develop in the surrounding environment or the form of values of special skills achieved by a person or group of people in achieving a certain level.

\subsection{Learning Strategies}

Kemp, as quoted by Sanjaya (2013: 187) explains that learning strategies are learning activities that must be done by teachers and students so that learning objectives can be achieved effectively and efficiently. Furthermore, Seels and Richey (1994: 34) explain that learning strategies are specifications for selecting and sorting learning events or learning activities in a lesson. Learning activities include presenting material, giving examples, giving training, and giving feedback. In order for learning objectives to be achieved optimally, all activities must 
be regulated by considering the characteristics of students, the media, and the situation around the learning process

Gerlach and Ely in Uno (2008: 1) explain learning strategies are ways chosen to convey learning methods in a particular learning environment that includes the nature of the scope and sequence of learning activities that can provide learning experiences to students. Meanwhile Gropper in Uno (2008: 1) explained the learning strategy is the selection of various types of specific exercises that are suitable for the learning objectives to be achieved.

Siregar and Nara (2011: 77) learning strategies are systematic ways that are chosen and used by a learning person to deliver learning material, thus facilitating learning to achieve certain learning goals. Reigeluth in Rusmono (2012: 21) describes learning strategies as general guidelines that contain different components of learning in order to be able to achieve the desired output optimally under the conditions created. Through the implementation of learning strategies it is expected that the learning outcomes can run effectively and efficiently and have its own charm.

\subsection{Background of Education}

Student education background is an important factor that must be considered by teachers in developing learning planning. Philosophically, it is not enough to study the initial behavior of students who come from Islamic Elementary School (MI) and Elementary School (SD), not just by looking at MI or SD labels. The difference between MI and SD is not only in the definition, organizational structure and purpose of education, but also in other aspects that are closely related to curriculum planning which includes: education orientation, curriculum focus, sensitivity to community development and others.

In connection with the above, Joni (1997: 16) explains education is; (1) is a process of human interaction characterized by the balance of sovereignty of students with the authority of educators, (2) education is an effort to prepare students to face the environment that experiences rapid changes. (3) education improves the quality of personal life that is increasingly rapid. (4) education lasts a lifetime. (5) education is a trick in applying the principles of science and technology to the formation of whole people. With the understanding above, it is clear that education is an activity in which interactions occur between individuals and the environment both human environment, nature and circumstances.

The substance that distinguishes between MI and SD will be reflected in the curriculum dimension. The curriculum is a study program, as a planned learning experience, as a structured and expected learning outcome as well as a written activity plan. Thus in comparing the learning outcomes of Fiqh Jurisprudence between students from MI with those from elementary school philosophically, at least the number of hours of lessons must be seen from subjects that support the formation of a mindset that leads to the ability to solve Fiqh Jurisprudence questions. In the teaching and learning process, the learning outcomes obtained by students can be influenced by various factors, including there are quite dominant factors, namely the knowledge students have had at the previous level of education.

\section{Research Methods}

This research was carried out at Islamic Junior High Public School (MTsN 1) Simalungun. This location was chosen considering that there had not been any research in this 
location previously related to the title of this research. The time of the study was carried out on odd cement school year 2018-2019.

The method used in this study is a quasi-experimental method. This method was chosen because the class used for treatment for both the generative learning class and the expository learning class is a pre-formed class and the characteristics of the students being controlled are the educational background of the study.

The population of this study was all seventh grade students of MTsN 1 Simalungun consisting of 5 classes. The characteristics of MTsN 1 Simalungun students scattered in the 5 classes are not grouped on the rankings and classifications of superior classes but the distribution of students into the 5 classes is done randomly during the placement of students in their respective class groups.

The sampling technique is used cluster random sampling. This technique was chosen because sampled from the population was the number of classes (as many as 5 classes) rather than the number of students in the population. The sample taken consisted of two groups, namely one class group conducted learning using generative learning and one other class carried out expository learning.

\section{Discussions}

Data on Fiqh Jurisprudence learning outcomes for MTsN 1 Simalungun students taught with generative learning strategies is known to mean $=28.12$; modus $=28.34$; median $=28.10$; varians $=16.11$; standard deviation $=4.01$; maximum score $=36$; and minimum score $=20$. An overview of the distribution of Jurisprudence learning outcomes for MTsN 1 Simalungun students taught with generative learning strategies as a whole can be seen in Table 4.2 below:

Table 4.2. Description of the learning outcomes of Fiqh Jurisprudence taught with generative learning strategy

\begin{tabular}{|c|c|c|}
\hline Interval Class & $\mathrm{f}_{\text {absolute }}$ & $\mathrm{f}_{\text {relative }}$ \\
\hline $19-21$ & 1 & 2,94 \\
\hline $22-24$ & 6 & 17,65 \\
\hline $25-27$ & 8 & 23,53 \\
\hline $28-30$ & 10 & 29,41 \\
\hline $31-33$ & 5 & 14,71 \\
\hline $34-36$ & 4 & 11,76 \\
\hline Total & 34 & 100 \\
\hline
\end{tabular}

Based on the data in Table 4.2 it can be explained that with a mean of 28.12 in the interval class $28-30$, this means that there are $29.41 \%$ of respondents in the class average score, $44.12 \%$ below the class average score and $26.47 \%$ above the class average score. 
Data of Fiqh Jurisprudence learning outcomes for MTsN1 Simalungun students taught with expository learning strategies are known to mean $=27.00$; mode $=26.50$; median $=26.95$; variance $=15.77 ;$ standard deviation $=3.97$; maximum score $=34$; and minimum score $=19$.

The description of Fiqh Jurisprudence learning outcomes score contribution of students of MTsN 1 Simalungun taught with expository learning strategies presented in Table 4.3 below:

Table 4.3 Description of the learning outcomes of Fiqh Jurisprudence taught with Expository learning strategy

\begin{tabular}{|c|c|c|}
\hline Interval Class & $\mathrm{f}_{\text {absolute }}$ & $\mathrm{f}_{\text {relative }}$ \\
\hline $19-21$ & 3 & 7,90 \\
\hline $22-24$ & 7 & 18,42 \\
\hline $25-27$ & 11 & 28,95 \\
\hline $28-30$ & 9 & 23,68 \\
\hline $31-33$ & 6 & 15,79 \\
\hline $34-36$ & 2 & 5,26 \\
\hline Total & 38 & 100 \\
\hline
\end{tabular}

Based on the data in Table 4.3 it can be explained that with a mean of 27 in the interval class $25-27$, this means that there are $28.95 \%$ of respondents in the class average score, $26.32 \%$ below the class average score and 44,73\% above the class average score.

Data of Fiqh Jurisprudence learning outcomes for students of MTsN 1 Simalungun with Islamic elemtary schooh (MI) education background taught with generative learning strategies and expository learning strategies are known to mean $=29.61$; mode $=30$; median $=29.76$; variance $=8.84 ;$ standard deviation $=2.97$; maximum score $=36$; and minimum score $=23$.

Distribution of Fiqh Jurisprudence learning data for MTsN 1 Simalungun students with MI education background taught with generative learning strategies and expository learning strategies are presented in Table 4.4. as follows:

Table 4.4 Description of students' learning outcomes of Fiqh Jurisprudence with MI education background

\begin{tabular}{|c|c|c|}
\hline Interval Class & $\mathrm{f}_{\text {absolute }}$ & $\mathrm{f}_{\text {relative }}$ \\
\hline $23-25$ & 3 & 9,68 \\
\hline $26-28$ & 7 & 22,58 \\
\hline $29-31$ & 13 & 41,94 \\
\hline $32-34$ & 7 & 22,58 \\
\hline $35-37$ & 1 & 3,22 \\
\hline Total & 31 & 100 \\
\hline
\end{tabular}


Based on the data in Table 4.4 it can be explained that with the mean of 29.61 in the interval class 29-31, this means that there are $41.94 \%$ of respondents in the class average score, $32.26 \%$ below the class average score and $25.80 \%$ above the class average score.

Data of Fiqh Jurisprudence learning outcomes of students of MTsN 1 Simalungun with elementary school (SD) education background taught with generative and expository learning strategies, namely mean $=25.93$; mode $=25.4$; median $=25.67$; variance $=13.26$; standard deviation $=3.64$; maximum score $=34$; and minimum score $=19$.

Distribution of Fiqh Jurisprudence learning outcomes data for MTsN 1 Simalungun students with elementary school (SD) education background are presented in Table 4.5 below:

Table 4.5 Description of students' learning outcomes of Fiqh Jurisprudence with SD education background

\begin{tabular}{|c|c|c|}
\hline Interval Class & $\mathrm{f}_{\text {absolute }}$ & $\mathrm{f}_{\text {relative }}$ \\
\hline $19-21$ & 4 & 9,76 \\
\hline $22-24$ & 11 & 26,83 \\
\hline $25-27$ & 14 & 34,15 \\
\hline $28-30$ & 7 & 17,07 \\
\hline $31-33$ & 4 & 9,76 \\
\hline $34-36$ & 1 & 2,43 \\
\hline Total & 41 & 100 \\
\hline
\end{tabular}

Based on the data in Table 4.5, it can be explained that with the mean of 25.93 in the interval class $25-27$, this means there are $34.15 \%$ of respondents in the class average score, $36.59 \%$ below the class average score and $29.26 \%$ above the class average score.

Data of Fiqh Jurisprudence learning outcomes data of MTsN 1 Simalungun students taught with generative learning strategies and educational background of MI are known to mean $=31.21 ;$ mode $=30.10 ;$ median $=31.50 ;$ variance $=4.83 ;$ standard deviation $=2.19$; maximum score $=36$; and minimum score $=28$.

Distribution of Fiqh Jurisprudence learning outcomes scores of MTsN1 Simalungun students taught with generative learning strategies and MI education background are presented in Table 4.6. as follows:

Table 4.6 Description of learning outcomes data of students taught with Generative learning strategies and backgrounds MI education

\begin{tabular}{|c|c|c|}
\hline Interval Class & $\mathrm{f}_{\text {absolute }}$ & $\mathrm{f}_{\text {relative }}$ \\
\hline $27-28$ & 1 & 7,14 \\
\hline $29-30$ & 5 & 35,71 \\
\hline
\end{tabular}




\begin{tabular}{|c|c|c|}
\hline $31-32$ & 4 & 28,57 \\
\hline $33-34$ & 3 & 21,44 \\
\hline $35-36$ & 1 & 7,14 \\
\hline Total & 14 & 100 \\
\hline
\end{tabular}

Based on the data in Table 4.6 it can be explained that with a mean of 31.21 in the interval class $31-32$, this means that there are $28.57 \%$ of respondents in the class average score, $42.85 \%$ below the class average score and $28,58 \%$ above the class average score.

Data of Fiqh Jurisprudence learning outcomes MTsN 1 Simalungun students taught with generative learning strategies and elementary school (SD) education background are known to mean $=25 ;$ mode $=25.5 ;$ median $=25.5 ;$ variance $=6.95 ;$ standard deviation $=2.63 ;$ maximum score $=31 ;$ and minimum score $=20$.

The description of the distribution of scores on the Jurisprudence learning outcomes data of MTsN 1 Simalungun students taught with generative learning strategies and elementary school (SD) education background is presented in Table 4.7 as follows:

Table 4.7 Description of student learning outcomes data taught by strategy Generative learning and elementary education background

\begin{tabular}{|c|c|c|}
\hline Interval Class & $\mathrm{f}_{\text {absolute }}$ & $\mathrm{f}_{\text {relative }}$ \\
\hline $20-21$ & 1 & 5,00 \\
\hline $22-23$ & 4 & 20,00 \\
\hline $24-25$ & 5 & 25,00 \\
\hline $26-27$ & 5 & 25,00 \\
\hline $28-29$ & 4 & 20,00 \\
\hline $30-31$ & 1 & 5,00 \\
\hline Total & 20 & 100 \\
\hline
\end{tabular}

Based on the data in Table 4.7, it can be explained that with the mean of 25 in the interval class $24-25$, this means that there are $25.00 \%$ of respondents in the class average score, $25.00 \%$ below the class average score and $50.00 \%$ above the class average score.

Data of Fiqh Jurisprudence learning outcomes MTsN 1 Simalungun students taught with expository learning strategies and educational background of MI are known to mean $=28$; mode $=28.5 ;$ median $=28.25 ;$ variance $=8.47 ;$ standard deviation $=2.91 ;$ maximum score $=$ 34 ; and minimum score $=23$.

Distribution of Fiqh Jurisprudence learning outcomes scores of MTsN 1 Simalungun taught with expository learning strategies and MI education background are presented in Table 4.8 as follows: 
Table 4.8 Description of data on student learning outcomes taught by strategy Expository learning and educational background of MI

\begin{tabular}{|c|c|c|}
\hline Interval Class & $\mathrm{f}_{\text {absolute }}$ & $\mathrm{f}_{\text {relative }}$ \\
\hline $23-24$ & 2 & 11,76 \\
\hline $25-26$ & 3 & 17,65 \\
\hline $27-28$ & 4 & 23,53 \\
\hline $29-30$ & 4 & 23,53 \\
\hline $31-32$ & 3 & 17,65 \\
\hline $33-34$ & 1 & 5,88 \\
\hline Total & 17 & 100 \\
\hline
\end{tabular}

Based on the data in Table 4.8 it can be explained that with a mean of 28 in the interval class $27-28$, this means there are $23.53 \%$ of respondents in the class average score, $29.41 \%$ below the class average score and $47.06 \%$ above the class average score.

Data of Fiqh Jurisprudence learning outcomes MTsN 1 Simalungun who were taught with expository learning strategies and elementary school (SD) education background known mean $=26.14 ;$ mode $=25.25 ;$ median $=25.76 ;$ variance $=18.42 ;$ standard deviation $=4.29$; maximum score $=34$; and minimum score $=19$.

Distribution of fiqhv Jurisprudence learning outcomes scores of MTsN 1 Simalungun students taught with expository learning strategies and SD education background are presented in Table 4.9 as follows:

Table 4.9 Description of student learning outcomes data taught by strategy Expository learning and SD education background

\begin{tabular}{|c|c|c|}
\hline Interval Class & $\mathrm{f}_{\text {absolute }}$ & $\mathrm{f}_{\text {relative }}$ \\
\hline $19-21$ & 3 & 14,29 \\
\hline $22-24$ & 5 & 23,81 \\
\hline $25-27$ & 6 & 28,57 \\
\hline $28-30$ & 3 & 14,29 \\
\hline $31-33$ & 3 & 14,29 \\
\hline $34-36$ & 1 & 4,75 \\
\hline Total & 21 & 100 \\
\hline
\end{tabular}


Based on the data in Table 4.9, it can be explained that with the mean of 26.14 in the interval class $25-27$, this means that there are $28.57 \%$ of respondents in the class average score, $38.10 \%$ below the class average score and $33,33 \%$ above the class average score.

\section{Testing Requirements for Analysis}

Testing the requirements for the analysis of data from research results in this case is the data on Fiqh Jurisprudence learning outcomes of students of MTsN 1 Simalungun conducted through testing the normality test and homogeneity test.

Testing the normality of Fiqh Jurisprudence learning outcomes data of MTsN 1 Simalungun students is intended to find out whether the data on learning outcomes of Religious Education are normally distributed or not. The normality testing of this data is important because normally the data in quantitative research is a condition that must be met to conduct further testing, namely testing the hypothesis.

Normality testing was carried out by Liliefors test. The complete calculation can be seen in Appendix 10. The summary calculation of the normality testing of the Jurisprudence learning outcomes of students of MTsN 1 Simalungun with the Liliefors formula can be seen in Table 4.10.

Table 4.10 Summary of Normality Test Analysis

\begin{tabular}{|c|c|c|c|c|}
\hline No & Group & Lobservation & $\mathrm{L}_{\text {table }}$ & Information \\
\hline 1 & $\begin{array}{l}\text { Fiqh Jurisprudence Learning Outcomes of } \\
\text { MTsN } 1 \text { Simalungun Students Taught With } \\
\text { Generative Strategies }\end{array}$ & 0,0735 & 0,1519 & Normal \\
\hline 2 & $\begin{array}{l}\text { Fiqh Jurisprudence Learning Outcomes of } \\
\text { MTsN } 1 \text { Simalungun Students Taught With } \\
\text { Expository Strategies }\end{array}$ & 0,0862 & 0,1437 & Normal \\
\hline 3 & $\begin{array}{l}\text { Figh Jurisprudence Learning Outcomes of } \\
\text { Simalungun } 1 \text { MTs Negeri } 1 \text { Students With } \\
\text { Educational Background MI }\end{array}$ & 0,0678 & 0,1591 & Normal \\
\hline 4 & $\begin{array}{l}\text { Fiqh Jurisprudence Learning Outcomes of } \\
\text { MTsN } 1 \text { Simalungun Students with SD } \\
\text { education background }\end{array}$ & 0,1353 & 0,1383 & Normal \\
\hline 5 & $\begin{array}{l}\text { Fiqh Jurisprudence Learning Outcomes of } \\
\text { Students of MTsN } 1 \text { Simalungun Which Are } \\
\text { Taught With Generative Strategies and } \\
\text { Educational Background of MI }\end{array}$ & 0,1374 & 0,227 & Normal \\
\hline 6 & $\begin{array}{l}\text { Fiqh Jurisprudence Learning Outcomes of } \\
\text { Students of MTsN } 1 \text { Simalungun Which Are } \\
\text { Taught With Generative Strategies and SD } \\
\text { Education Background }\end{array}$ & 0,1264 & 0,190 & Normal \\
\hline
\end{tabular}




\begin{tabular}{|c|l|c|c|c|}
\hline 7 & $\begin{array}{l}\text { Fiqh Jurisprudence Learning Results of } \\
\text { MTsN 1 Simalungun Students Taught With } \\
\text { Expository Strategies and Educational } \\
\text { Background of MI }\end{array}$ & 0,0927 & 0,206 & Normal \\
\hline 8 & $\begin{array}{l}\text { Fiqh Jurisprudence Learning Outcomes of } \\
\text { Students of MTsN 1 Simalungun That Are } \\
\text { Taught With Expository Strategies and SD } \\
\text { Education Background }\end{array}$ & 0,1740 & 0,186 & Normal \\
\hline
\end{tabular}

Normality test of Fiqh Jurisprudence learning outcomes data of students of MTsN 1 Simalungun taught with generative learning strategies obtained Liliefors count value of 0.0735 while the Liliefors value of tables with $\mathrm{N}=34$ and $\alpha=0.05$ is 0.1519 . Thus it is known that the Liliefors value is smaller than the Liliefors table value which is $0.0735<0.1519$ so that it can be concluded that the Jurisprudence learning outcomes data of MTsN 1 Simalungun students taught with generative learning strategies are normally distributed.

Normality test of Fiqh Jurisprudence learning outcomes for students of MTsN 1 Simalungun taught by expository learning strategies obtained by Liliefors count value of 0.0862 while the Liliefors value of tables with $\mathrm{N}=38$ at $\alpha=0.05$ is 0.1437 . Thus, it is known that the Liliefors value is smaller than the Liliefors table value which is $0.0862<0.1437$ so it can be concluded that the data on Jurisprudence learning outcomes of the students of MTsN 1 Simalungun is normally distributed.

Normality test of Fiqh Jurisprudence learning data for students of MTsN 1 Simalungun with an overall educational background of MI taught by generative learning strategies and expository learning strategies obtained Liliefors count value of 0.0678 while the Liliefors table value with $\mathrm{N}=31$ at $\alpha=0.05$ which is 0.1591 . Thus it is known that the Liliefors value is smaller than the Liliefors table value which is $0.0678<0.1591$ so it can be concluded that the data on Jurisprudence learning outcomes of students of MTsN 1 Simalungun are normally distributed.

Normality test of Fiqh Jurisprudence learning data for students of MTsN 1 Simalungun with elementary school (SD) education background taught with generative learning strategies and expository learning strategies obtained Liliefors count value of 0.1353 while Liliefors table value with $\mathrm{N}=41$ at $\alpha=0.05$, namely 0,1383 . Thus it is known that the Liliefors value is smaller than the Liliefors table value which is $0.1353<0.1383$, it is concluded that the data from the Jurisprudence learning outcomes of the students of MTsN 1 Simalungun is normally distributed.

Normality test of Fiqh Jurisprudence learning outcomes for students of MTsN 1 Simalungun taught by generative learning strategies and MI education background obtained Liliefors count value of 0.1374 while Liliefors table value with $\mathrm{N}=14$ at $\alpha=0.05$, which is 0.227. Thus, it is known that the Liliefors value is smaller than the Liliefors table value which is $0.1374<0.227$. It can be concluded that the Fikih learning outcomes data of students of MTsN 1 Simalungun taught with generative learning strategies and MI educational backgrounds are normally distributed.

Normal test of Fiqh Jurisprudence learning outcome data of students of MTsN 1 Simalungun who were taught with generative learning strategies and elementary education background obtained Liliefors count value of 0.1264 while Liliefors table value with $\mathrm{N}=20$ at 
$\alpha=0.05$ which is 0.190 . Thus it is known that the Liliefors value is smaller than the Liliefors table value which is $0.1264<0.190$, so it is concluded that the Jurisprudence learning outcomes data of MTsN 1 Simalungun students taught with generative learning strategies and elementary education background are normally distributed.

Normality test of Fiqh Jurisprudence learning outcomes for students of MTsN 1 Simalungun Simalungun taught by expository learning strategies and MI education background obtained Liliefors count value of 0.0927 while Liliefors table value with $\mathrm{N}=17$ at $\alpha=0.05$, 0.206 . Thus, it is known that the Liliefors value is smaller than the Liliefors table value which is $0.0927<0.206$, so it is concluded that the Jurisprudence learning outcomes data of MTsN 1 Simalungun students taught with expository learning strategies and MI education background are normally distributed.

Normal test of Fiqh Jurisprudence learning outcome data of MTsN 1 Simalungun students taught with expository learning strategies and elementary education background obtained Liliefors count value of 0.1740 while Liliefors table value with $\mathrm{N}=21$ at $\alpha=0.05$ which is 0.186 . Thus, it is known that the Liliefors value is smaller than the Liliefors table value which is $0.1740<0.186$. It can be concluded that the Jurisprudence learning outcomes data of MTsN 1 Simalungun students taught with generative learning strategies as a whole students with elementary education background are normally distributed.

Testing the variance homogeneity of Fiqh Jurisprudence learning outcomes data for students of MTsN 1 Simalungun was conducted to determine whether the sample variance originated from a homogeneous population or not. The homogeneity test is done by comparing the variance of Jurisprudence learning outcomes data of MTsN 1 Simalungun students between treatments taught with generative learning strategies with expository learning strategies and learning independence.

Summary of test calculations for homogeneity of Fiqh Jurisprudence learning outcomes data for students of MTsN 1 Simalungun can be seen in Table 4.11.

Table 4.11 Summary of Analysis of Student Homogeneity Tests Students Who Are Taught With Generative Strategies and Expository Strategy

\begin{tabular}{|l|c|c|c|}
\hline \multicolumn{1}{|c|}{ Sample group } & $\mathrm{F}_{\text {Count }}$ & $\mathrm{F}_{\text {Table }}$ & Information \\
\hline $\begin{array}{l}\text { Students Who Are Taught With Generative } \\
\text { Strategies and Expository Strategies }\end{array}$ & 1,02 & 1,73 & Homogeneous \\
\hline
\end{tabular}

Based on the data in the table above, the results of the homogeneity test of the learning outcomes of Jurisprudence data groups of students of MTsN 1 Simalungun taught by generative learning strategies and expository learning strategies obtained $\mathrm{F}_{\text {count }}$ values of 1.02 while the $\mathrm{F}_{\text {- }}$ table value $=1.73$ at $\alpha=0,05$ with a numerator 33 and a denominator 37 . Thus, it is known that the value of $\mathrm{F}_{\text {Count }}$ is smaller than the value of the $\mathrm{F}_{\text {-table }}$ table which is $1.02<1.73$, it can be concluded that the two learning outcomes data of MTsN 1 Simalungun students have variances that relatively similar (homogeneous). 
Table 4.12 Summary of Student Homogeneity Test Analysis with Background on MI and Background Education behind Elementary Education

\begin{tabular}{|c|c|c|c|}
\hline Sample group & $\mathrm{F}_{\text {Count }}$ & $\mathrm{F}_{\text {Table }}$ & Information \\
\hline $\begin{array}{l}\text { Educational background of MI and } \\
\text { Educational background of SD }\end{array}$ & 1,5 & 1,74 & Homogeneous \\
\hline
\end{tabular}

Based on the data in the table above, the results of the homogeneity test of the data on Fiqh Jurisprudence learning outcomes in the sample group of MTsN 1 Simalungun students with MI educational background and elementary education background obtained a calculated $\mathrm{F}_{\text {Count }}$ value of 1.5 while the $\mathrm{F}_{\text {-table }}$ value $=1.74$ at $\alpha=0.05$ with a numerator of 30 and a denominator of 40 , so that it is known that the value of $F_{\text {Count }}$ is smaller than the value of the table $\mathrm{F}_{\text {-table }}$ which is $1.5<1.74$. It can be concluded that the data of the MTsN 1 Simalungun study group has relatively equal (homogeneous) variance.

Table 4.13 Summary of Homogeneity Analysis of Learning Strategies And Educational Background

\begin{tabular}{|l|c|c|c|}
\hline \multicolumn{1}{|c|}{ Sample group } & $\chi^{2}$ count & $\chi^{2}$ table & Information \\
\hline $\begin{array}{l}\text { Interaction of Learning Strategies and } \\
\text { Educational Background }\end{array}$ & 6,33 & 7,81 & Homogeneous \\
\hline
\end{tabular}

Based on the data in the table above, the results of the homogeneity test of interactions between learning strategies and educational backgrounds used the Bartlett formula. Based on the calculation of the Bartlett formula obtained the $\chi^{2}$ count $=6.33$ while the price of $\chi^{2}$ table $(\alpha=0.05,3)=7.81$. Based on these data, it can be seen that the price of $\chi^{2}$ count $<\chi^{2}$ tables, so that it can be concluded that the learning outcomes of Fiqh Jurisprudence of MTsN 1 Simalungun students come from homogeneous variations.

The results of this study can be said that the learning strategy must be adapted to the characteristics of student that is educational background and subject matter to be delivered. The selection of learning strategies or the ability to design appropriate Jurisprudence learning is needed and must be adapted to the characteristics of students so that it will help in determining learning strategies, learning theories, and learning media suitable for use. This is done so that the lessons delivered can attract students' attention and every lesson does not feel boring.

\section{Conclusion}

There is the influence of the application of generative learning strategies to the learning outcomes of Jurisprudence. This can be seen from the difference in the average learning outcomes of students taught with generative learning strategies $(\bar{X}=28.12)$ as a whole higher than the average learning outcomes of students of MTsN 1 Simalungun taught by expository learning strategies $(\bar{X}=27.00)$ Thus the generative learning strategy is more effectively applied in Jurisprudence learning to improve student learning outcomes without regard to differences in learning education backgrounds as evidenced by the $\mathrm{F}_{\text {Count }}$ value of 113.96> $\mathrm{F}_{\text {Table }}$ 3.984 .

There is an influence of educational background on the results of Jurisprudence learning. This can be seen from the difference in the average learning outcomes of students of MTsN 1 
Simalungun with an educational background of MI ( $\bar{X}=29.61)$ taught by generative learning strategies and expository learning strategies higher than the average learning outcomes of students with educational backgrounds Elementary School $(\bar{X}=25.93)$. This is also evidenced by the price of $F_{\text {count }} 7.66>F_{\text {table }} 3.984$.

The results of the calculation of statistical analysis show that there is an interaction between learning strategies with educational backgrounds, where students with MI educational backgrounds are better taught using generative learning strategies compared to using expository learning strategies, while students with elementary education background are better taught by using expository learning strategies compared to generative learning strategies. This is evidenced by the price of $F_{\text {coun } 35.48>~} F_{\text {table }} 3.984$.

The results show that there is an interaction between learning strategies with educational backgrounds, where students with an educational background in islamic elementary school (MI) are better taught using generative learning strategies compared to using expository learning strategies, while students with educational background in elementary school (SD) is better taught by using expository learning strategies compared to generative learning strategies. This is evidenced by the price of $F_{\text {count }} 35.48>F_{\text {table }} 3.984$.

\section{References}

Abror, R. Psikologi Pendidikan. Yogyakarta: Tiara Wacana, 2003.

Anderson, O.W. dan Krathwohl, D.R. A Taxonomy for Learning, Teaching, and Assesing: A Revision of Bloom's Taxonomy of Educational Objectives, New York; Longman, 2001.

Arikunto, Suharsimi. Dasar-Dasar Evaluasi Pendidikan. Jakarta: Bumi Aksara, 2005.

Aunurrahman. Belajar Dan Pembelajaran. Bandung: Alfabeta, 2011.

Bot, Thomas D. On The Effects of Generative Learning Strategy on Students' Understanding and Performance in Geometry in Lafia Metropolis, Nasarawa State, Nigeria. Jurnal: International Journal of Humanities and So cial Science Invention (IJHSSI) ISSN (Online): 2319 - 7722, ISSN (Print): 2319 - 7714 www.ijhssi.org ||Volume 7 Issue 03 Ver. III March. 2018.

Darmayanti, Nefi. Psikologi Belajar. Bandung: Citapustaka, 2009.

Dimyati dan Moedjiono. Belajar dan Pembelajaran, Jakarta: Rineka Cipta, 1999.

Effendi, E. Usman dan Praja, Juhaya S. Pengantar Psikologi. Bandung: Angkasa, 1985.

Gulo, W. Strategi Belajar Mengajar. Jakarta: Grasindo, 2008.

Karpov, Alexander O. Generative Learning in Research Education for the Knowledge Society. Jurnal: IEJME Mathematics Education Vol. 11, No. 6, 2016.

Komalasari, Kokom. Pembelajaran Kontekstual Konsep Dan Aplikasi. Bandung: Refika Aditama, 2010.

Lie, Anita. Cooperative Learning. Mempraktekkan Cooperative Learning di Ruang-ruang kelas. Jakarta: Grasindo, 2004.

Maknun, Johar. The Implementation of Generative Learning Model on Physics Lesson to Increase Mastery Concepts and Generic Science Skills of Vocational Students. American Journal of Educational Research, Vol. 3, No. 6, 2015.

Mardianto. Psikologi Pendidikan Landasan Bagi Pengembangan Strategi Pembelajaran. Bandung: Citapustaka.

Nurmawati. Evaluasi Pendidikan Islami. Bandung: Citapustaka, 2016.

Pribadi, Benny A. Model Desain Sistem Pembelajaran. Jakarta: Dian Rakyat, 2011. 
Quthb, Sayyid. Tafsir Fi Zhilalil Qur'an. Jakarta: Gema Insani Press. 2003.

Reid, A. J., dan Morrison, G. Generative Learning Strategy Use And Self-Regulatory Prompting In Digital Text. Jurnal: Journal of Information Technology Education: Research Volume 13, 2014.

Rohani, Ahmad dan Ahmadi, Abu. Pengelolaan Pengajaran. Jakarta: Rineka Cipta, 1995.

Rusmono, Strategi Pembelajaran Dengan Problem Based Learning Itu Perlu Untuk Meningkatkan Porfesionalitas Guru. Bogor: Ghalia Indonesia, 2012.

Rusyan, A. Tabrani., Kusdinar, Atang dan Arifin, Zainal. Pendekatan Dalam Proses Belajar Mengajar. Bandung: Remaja Rosdakarya, 1994.

Sagala, Syaiful. Konsep dan Makna Pembelajaran. Bandung: Alfabeta, 2012.

Sanjaya, Wina. Strategi Pembelajaran, Berorientasi Standar Proses Pendidikan. Jakarta: Prenada Media Group, 2014. Group, 2013. Perencanaan Dan Desain Sistem Pembelajaran. Jakarta: Prenada Media

Seels, Barbara B dan Richey, Rita. C. Instructional Technology; The Definition And Domains of The Field. Washington: AECT, Alihbahasa: Dewi S. Prawiradilaga, Raphael Rahardji dan Yusufhadi Miarso. Jakarta: Universitas Negeri Jakarta, 1994.

Shaffat, Idris. Optimized Learning Strategy Pendekatan Teoretis Dan Praktis Meraih Keberhasilan Belajar. Jakarta: Prestasi Pustaka.

Siregar, Eveline dan Nara, Hartini. Teori Belajar Dan Pembelajaran. Bogor: Ghalia Indonesia, 2011.

Slameto. Belajar dan Faktor-Faktor Yang Mempengaruhinya. Jakarta: Rineka Cipta, 2005.

Sopiatin, Popi dan Sahrani, Sohari. Psikologi Belajar Dalam Perspektif Islam. Bogor: Ghalia Indonesia, 2011.

Sudjana, Nana. Dasar-Dasar Proses Belajar Mengajar. Jakarta; Sinar Baru Algensindo, 2002. Cara Belajar Siswa Aktif Dalam Proses Belajar Mengajar. Bandung: Sinar Baru Algensindo, 1996.

Sudjana, D.S. Metode Dan Teknik Pembelajaran Partisipatif, Bandung: Falah Production, 2001.

Suparman, M. Atwi. Desain Instruksional Modern Panduang Para Pengajar Dan Inovator Pendidikan. Jakarta: Erlangga, 2012.

Surapranata, Sumarna. Analisis Validitas, Reliabilitas dan Interpretasi Hasil Tes, Bandung: Remaja Rosdakarya, 2004.

Syah, Muhibbin. Psikologi Pendidikan Dengan Pendekatan Baru. Bandung: Remaja Rosdakarya, 2010.

Uno, Hamzah B. Model Pembelajaran Menciptalan Proses Belajar Mengajar Yang Kreatif dan Efektif. Jakarta: Bumi Aksara, 2008.

Wena, Made. Strategi Pembelajaran Inovatif Kontemporer. Jakarta: Bumi Aksara, 2009.

Winkel W.S. Psikologi Pembelajaran. Jakarta: Rineka Cipta, 2001.

Yaumi, Muhammad. Prinsip-Prinsip Desain Pembelajaran. Jakarta: Prenada Media Group. 2013. 